\title{
Effects of manganese on physiological characters of grapevine cultivars under salinity stress
}

\begin{abstract}
Salinity is one of the most important environmental factors which have a significant effect on the growth and fertility. Manganese is an essential element that plays a key role as a nutrient in many plant metabolic processes. The present study was carried out to investigate the effects of manganese (1ppm) on Yaghoti and Ghara uzum - two cultivars of grapevine - which were planted and grown under salt stress $\left(0,50\right.$ and $\left.100 \mathrm{mmol} \mathrm{L}^{-1} \mathrm{NaCl}\right)$ using greenhouse and hydroponics methods. Results on saline concentration showed led to a significant decrease in length, fresh and dry weight, photosynthesis pigments content, $\mathrm{K}^{+}$ and nitrate content, and $\mathrm{K}^{+} / \mathrm{Na}^{+}$ratio of the plants. It also caused a significant increase in $\mathrm{Na}^{+}$ and $\mathrm{Cl}^{-}$ion concentration and soluble sugar content in shoots and roots of both cultivars. Ghara uzum was more sensitive than Yaghoti to salinity stress. Applying manganese to the medium, resulted in low level of salinity toxicity and sodium ion accumulation in the shoots for Ghara uzum cultivar. For Yaghoti, however, the application of manganese did not reduce the sodium ion accumulation in the shoots, but increased the salinity toxicity. Our findings suggest that Ghara uzum and Yaghoti cultivars had different responses to salinity, manganese and their interaction.
\end{abstract}

Keywords: salinity, manganese, grapevine, ions accumulation, nitrate content, photosynthesis pigments
Volume 5 Issue 2 - 2020

\author{
Sepideh Hatami,' Latifeh Pourakbar ${ }^{2}$ \\ 'Agriculture and Natural Resource Research and Education \\ Center of West Azarbaijan, Agriculture Research and Education \\ Organization, Iran \\ 2Department of Biology, Faculty of Sciences, Urmia University, \\ Iran
}

Correspondence: Sepideh Hatami,Agriculture and Natura Resource Research and Education Center of West Azarbaijan, Agriculture Research and Education Organization, Urmia, Iran, Tel 98914141921।,Email s.hatami@areeo.ac.ir

Received: January II, 2020 | Published: April 03, 2020

\section{Introduction}

Plants grown in arid and semi-arid regions are usually subjected to adverse environmental factors such as high salinity or drought. Salinity has unfavorable effects on the growth and development of plants in 20percent of arable lands of the world. ${ }^{1}$ The most common effect of saline soils on plants is growth inhibition, often related to high density of $\mathrm{Na}^{+}$and deficiency of $\mathrm{K}^{+}$. The accumulation of $\mathrm{Cl}^{-}$in the shoots is also harmful to the plant growth. ${ }^{3}$ Salinity has a variety of effects on plants' physiological processes reduces the leaf net $\mathrm{CO}_{2}$ assimilation rate and efficiency of photosynthesis. ${ }^{4}$

In other study accomplished by R, M Steven in 2011, $\mathrm{Cl}^{-}$uptake was greatest when saline irrigation was applied early in organ formation, whereas $\mathrm{Na}^{+}$uptake reflected seasonal salt load in irrigation water.

José M and Intrigliolo 2017 in a study reviewed the main findings obtained regarding the effects of deficit irrigation strategies, as well as irrigation with saline water, on the berry composition of both red and white cultivars, as well as on the final wine. A meta-analysis was performed using published data for red and white varieties; a general liner model accounting for the effects of cultivar, rootstock, and midday stem water potential was able to explain up to $90 \%$ of the variability in the dataset, depending on the selected variable. In both red and white cultivars, berry weight, must titratable acidity and $\mathrm{pH}$ were fairly well simulated, whereas the goodness-of-fit for wine attributes was better for white cultivars.

Manganese is an essential micronutrients for plant growth. ${ }^{5}$ It acts as a cofactor to many enzymes like Mn-superoxide dismutase, Mncatalase, pyruvate arboxylase, and phosphol pyrovate. ${ }^{6}$ The deficiency and toxicity of manganese are two nutritional diseases which influence the growth of various plants. ${ }^{7}$ limiting the photosynthetic rate and efficiency. Manganese is essential for chlorophyll synthesis and photosynthesis, ${ }^{8}$ nitrogen and carbohydrate metabolism, oxidation, and reduction and activation of some enzymes. However, a high level of Mn seems to damage the photosynthetic apparatus. ${ }^{9}$

The availability of Mn for plants depends on its amount in the soil, easily reducible $\mathrm{Mn}$ oxides, $\mathrm{pH}$ redox potential, soil humidity, and microbial activity. If $\mathrm{Mn}$ is available in excess, its high concentration in the plant tissue causes the appearance of toxicity symptoms and affects plant growth. ${ }^{5}$ The toxic symptoms of $\mathrm{Mn}$ include limited growth and photosynthesis rate, and appearance of chlorosis and necrotic brown spots on the leaves. ${ }^{9}$

Mn toxicity reduces photosynthesis, chlorophylls a and b contents, and other compounds such as carotenoids in plants. ${ }^{10}$ The damage threshold of Mn varies among to species and within genotypes of given species. ${ }^{11}$

The final destination of $\mathrm{Mn}^{2+}$ during the transportation in plant cells is the chloroplast and the deficiency of $\mathrm{Mn}^{2+}$ can cause photosynthesis reduction which in turn leads to growth inhibition by salinity. The ionic activity inhibition can occur during absorption of salinity major cations, namely $\mathrm{Na}^{+}$and $\mathrm{K}^{+} .{ }^{12}$

Our research aimed to study the effects of $\mathrm{Mn}$ on the growth, metabolism and ion accumulations in two cultivars of the grapevine under saline stress conditions .Grape is one of the major crop of West Azarbaijan's especially around the Urmia. Due to the shortage drop in rainfall, increasing drough, the growing danger of Urmia drying process, and the increase of the salt percentage of the nearby farmlands, 
specifying the proper cultivar matching with saltiness of the lands is of paramount importance and for the economic sustainability of viticulture in the region.

\section{Material and methods}

\section{Plant growth and experimental design}

Hardwood cuttings of two grapevines (Vitis vinifera L.) cultivars (Ghara uzum and Yaghoti) were obtained from Kahriz vineyard (Agricultural Research Center, Urmia, Iran). The cuttings were disinfected and then their basal parts were soaked in IBA (indol-3butyric acid) $0.1 \%(\mathrm{w} / \mathrm{v})$ for $5-10 \mathrm{~s}$. All cuttings were placed in a mist chamber (relative humidity $80 \%$ ) at $25-35^{\circ} \mathrm{C}$. After two weeks, the rooted cuttings were planted in pots filled with perlite and irrigated with $1 / 8$ strength Hoagland's solution containing $0.125 \mathrm{mM} \mathrm{KNO}_{3}$, $0.125 \mathrm{mM} \mathrm{Ca}\left(\mathrm{NO}_{3}\right)_{2}, 0.05 \mathrm{mM} \mathrm{MgSO}_{4} .7 \mathrm{H}_{2} \mathrm{O}, 0.0125 \mathrm{mM} \mathrm{KH}_{2} \mathrm{PO}_{4}$, $5.75 \mu \mathrm{M} \quad \mathrm{H}_{3} \mathrm{BO}_{3}, \quad 1.34 \mu \mathrm{M} \quad \mathrm{MnCl}_{2} .4 \mathrm{H}_{2} \mathrm{O}, \quad 0.1 \mu \mathrm{M} \quad \mathrm{ZnSO}_{4} .7 \mathrm{H}_{2} \mathrm{O}$, $0.038 \mu \mathrm{M} \mathrm{CuSO}_{4} .5 \mathrm{H}_{2} \mathrm{O}, 0.025 \mu \mathrm{M} \mathrm{Na}_{2} \mathrm{MoO}_{4} \cdot 2 \mathrm{H}_{2} \mathrm{O}$ and $8.88 \mu \mathrm{M} \mathrm{Fe}-$ EDTA. Cuttings with opened leaf bud were transferred to 2-1 aerated pots containing first $1 / 4$, then half and finally full strength Hoagland's solution, each for two weeks. Solutions were changed every two days and the nutrient concentrations and $\mathrm{pH}$ of the solutions were monitored daily (maintained within the $\mathrm{pH}$ range of 6.0-6.5). The pots were protected with aluminum foil to avoid light penetration and algal proliferation. Plants with 4-5 fully expanded leaves were treated with $\mathrm{NaCl}(0,50,100 \mathrm{mM} \mathrm{NaCl}), \mathrm{Mn}(1 \mathrm{ppm})$ and their interactions with $\mathrm{NaCl}(\mathrm{Mn}+50 \mathrm{mM} \mathrm{NaCl}$ and $\mathrm{Mn}+100 \mathrm{mM} \mathrm{NaCl})$ in full strength Hoagland solution for 2 weeks. $\mathrm{NaCl}$ was incrementally added to the nutrient solution at certain concentrations until the final desired concentrations were reached. Plants were harvested after 2 weeks and plant parts were weighed separately and dried at $70^{\circ} \mathrm{C}$ for 48 hours.

This experiment was conducted as based on completely randomized design (CRD) with two cultivars of grapevine and 6 treatments and 4 replications and each replication including three plants.

\section{Photosynthetic pigments}

The concentration of chlorophyll was determined using the spectrophotometeric method of Lichtenthaler and Wellburn. ${ }^{13}$ For this purpose, $5 \mathrm{~mL}$ of acetone $(80 \%)$ was added to $0.1 \mathrm{~g}$ leaf fresh weight and, then crushed and ground using mortar and pestle. After centrifugation of the samples at $3000 \mathrm{~g}$ (Dynamica model; Velocity, made in UK) for $10 \mathrm{~min}$, the supernatants were removed and the absorbance of the samples was read at wavelengths of 470,647 and $663 \mathrm{~nm}$ in a specterophotometers (Dynamica model; Halo DB-20, made in UK). The amount of these pigments was calculated according to the formulas of Lichtenthaler and Wellburn. ${ }^{13}$

\section{Determination of $\mathrm{Na}+, \mathrm{K}+$ and $\mathrm{Cl}-$}

The dried samples of shoot or root were powdered with mortar and pestle and then were digested following Allen et al. ${ }^{14}$ A flame photometer (Fater 405) was used for $\mathrm{Na}^{+}$and $\mathrm{K}^{+}$determination. A chloride analyzer (Corning 926) was used for determining $\mathrm{Cl}^{-}$contents in the extracts. $100 \mathrm{mg}$ of dry shoot or root materials was extracted in $10 \mathrm{~mL}$ of distilled water, heated at $70^{\circ} \mathrm{C}$ till the volume was almost halved and before determination the volume was again reached to $10 \mathrm{~mL}$ with distilled deionized water.

\section{Statistical analysis}

Data were analyzed with SPSS (ver. 19) package. In all graphs and tables, the results were expressed in average values of four replications \pm SE. The treatment effects were compared using the ANOVA and Duncan test at the $\mathrm{p}<0.05$ level of significance.

\section{Results}

Shoot and root lengths and fresh and dry weights decreased significantly $(\mathrm{p}<0.05)$ in both cultivars under salt and Mn stress (Table $1)$.

Table I Effects of Mn (I Ppm) on the growth parameters (root and shoot lengths and fresh and dry weights) in two grapevine cultivars (Yaghoti and Ghara uzum) under saline stress $(0,50$ and $100 \mathrm{mM} \mathrm{NaCl})$

\begin{tabular}{|c|c|c|c|c|c|c|c|}
\hline Cultivar & $\mathrm{NaCl}$ and $\mathrm{Mn}$ level & $\begin{array}{l}\text { Shoot } \\
\text { length }(\mathrm{cm})\end{array}$ & $\begin{array}{l}\text { Root } \\
\text { length }(\mathrm{cm})\end{array}$ & $\begin{array}{l}\text { Shoot fresh } \\
\text { weight (g) }\end{array}$ & $\begin{array}{l}\text { Root fresh } \\
\text { weight (g) }\end{array}$ & $\begin{array}{l}\text { Shoot dry } \\
\text { weight(g) }\end{array}$ & $\begin{array}{l}\text { Root dry } \\
\text { weight (g) }\end{array}$ \\
\hline \multirow{6}{*}{ Yaghoti } & 0 (Control) & $65 b$ & $35 b$ & $26.84 c$ & $7.41 d$ & $0.96 b c$ & $0.162 c$ \\
\hline & $50 \mathrm{mM} \mathrm{NaCl}$ & $46 \mathrm{de}$ & $23.6 \mathrm{e}$ & $21.21 \mathrm{de}$ & $5.53 \mathrm{e}$ & $0.58 \mathrm{de}$ & $0.075 f g$ \\
\hline & $100 \mathrm{mM} \mathrm{NaCl}$ & $38.8 f$ & $21.3 f$ & $7.4 \mathrm{Ig}$ & $2.52 \mathrm{~h}$ & $0.49 e$ & $0.049 \mathrm{~h}$ \\
\hline & Mn (Ippm) & $59 c$ & $28.1 \mathrm{~cd}$ & $26.30 c$ & $5.90 \mathrm{e}$ & $1.06 \mathrm{~b}$ & $0.131 d$ \\
\hline & $\mathrm{Mn}+50 \mathrm{mM} \mathrm{NaCl}$ & $48 d$ & $29.4 c$ & $16.01 \mathrm{e}$ & 4.9 If & $0.79 \mathrm{~cd}$ & $0.110 \mathrm{e}$ \\
\hline & $\mathrm{Mn}+100 \mathrm{mM} \mathrm{NaCl}$ & $42 e$ & $26.2 d$ & $12.32 \mathrm{f}$ & $3.63 \mathrm{~g}$ & $0.59 \mathrm{de}$ & $0.077 f g$ \\
\hline \multirow{6}{*}{ Ghara uzum } & 0 (Control) & $70 \mathrm{a}$ & $42.3 \mathrm{a}$ & $37.25 a$ & $11.10 \mathrm{a}$ & $2.1 \mathrm{a}$ & $0.332 \mathrm{a}$ \\
\hline & $50 \mathrm{mM} \mathrm{NaCl}$ & $57.6 c$ & $33.5 b$ & $25.83 c$ & $9.73 b$ & $0.88 c$ & $0.140 \mathrm{~cd}$ \\
\hline & $100 \mathrm{mM} \mathrm{NaCl}$ & $42.7 e$ & $23 e$ & I3.II ef & $2.8 \mathrm{Ih}$ & $0.69 d$ & $0.079 f$ \\
\hline & Mn (I Ippm) & $63.1 \mathrm{bc}$ & $30.1 \mathrm{c}$ & $33.05 b$ & $10.30 \mathrm{~b}$ & $0.89 c$ & $0.26 \mathrm{Ib}$ \\
\hline & $\mathrm{Mn}+50 \mathrm{mM} \mathrm{NaCl}$ & $56.2 \mathrm{~cd}$ & $33.02 \mathrm{bc}$ & $23.21 \mathrm{~d}$ & $8.52 c$ & $0.67 d$ & $0.082 f$ \\
\hline & $\mathrm{Mn}+100 \mathrm{mM} \mathrm{NaCl}$ & $38.4 f$ & $32.2 \mathrm{bc}$ & $12.50 f$ & 4.3 If & $0.44 \mathrm{e}$ & $0.06 \mathrm{lg}$ \\
\hline
\end{tabular}

Each value is the mean $( \pm S E)$ of four replicates. Different letters in each column show significant difference at $p<0.05$ by Duncan's Test 
Compared to the control groups, the concentration of $\mathrm{NaCl}$ ( 50 and $100 \mathrm{mM}$ ) in Yaghoti cultivar caused a decrease of $29-40 \%$ in shoot length, $32-39 \%$ in root length, $19-72 \%$ in shoot fresh weight, $25-66 \%$ in root fresh weight, $40-49 \%$ in shoot dry weight, and $54-70 \%$ in root dry weight. Reading Ghara uzum cultivar, there was a decrease of $18-40 \%$ in shoot length, $21-45 \%$ in root length, $32-65 \%$ in shoot fresh weight, $13-74 \%$ in root fresh weight, $58-67 \%$ in shoot dry weight, and $58-76 \%$ in root dry weight. Fresh and dry shoot biomasses of Yaghoti cultivar under salinity stress were higher than those of Ghara uzum (Table 1).

The interaction of Mn and salinity in the Ghara uzum cultivar led to a decrease of (2-10\% in shoot length, $4-8 \%$ in fresh shoot weight, $24-36 \%$ in dry shoot weight, and $25-43 \%$ in dry root weight. In the Yaghoti cultivar, this led to an improvement and increase in some growth parameters (4-10\% in shoot length, $77 \%$ in fresh shoot weight, $20-36 \%$ in dry shoot weight and $46-57 \%$ in root dry weight) compared to salinity alone (Table 1). The responses of the two studied grapevine cultivars were significantly different under salinity treatment alone and with interaction of $\mathrm{Mn}$ and salinity.

Due to salinity and Mn stress (Table 2), Chlorophylls $a$ and $b$ (Chl $a$ and $b$ ), the ratio of chl $a / b$, and the total carotenoids content of the leaves decreased significantly compared to the controls in both cultivars. Compared to the plants in the control group, the salinity stress decreased chlorophyll $a$ content by nearly $38-55 \%$ in Ghara uzum and $34-42 \%$ in Yaghoti, and reduced chlorophyll $b$ content by nearly $29-60 \%$ in Ghara uzum and $41-50 \%$ in Yaghoti. It also reduced carotenoids content about $68-92 \%$ in Ghara uzum and $64-58 \%$ in Yaghoti.

Table 2 Effects of Mn (Ippm) on total chlorophyll content (Total Chl), Chlorophyll a (Chl a), Chlorophyll b (Chl b), Chla/ Chl b ratio and carotenoid (Cx+c) (T car) in two grapevine cultivars (Yaghoti and Ghara uzum) under saline stress $(0,50$ and $100 \mathrm{mM} \mathrm{NaCl})$

\begin{tabular}{|c|c|c|c|c|c|c|}
\hline Cultivar & $\mathrm{NaCl}$ and $\mathrm{Mn}$ level & Chla & Chlb & Total chl & Chla/chlb & T Car \\
\hline \multirow{6}{*}{ Yaghoti } & 0 (Control) & $29.5 \mathrm{a}$ & $16.3 \mathrm{a}$ & $45.8 \mathrm{a}$ & $\mathrm{I} .8 \mathrm{Id}$ & $5.2 \mathrm{Ib}$ \\
\hline & $50 \mathrm{mM} \mathrm{NaCl}$ & $19.5 \mathrm{~d}$ & $9.6 c$ & $29.1 \mathrm{de}$ & $2.03 c$ & $1.89 \mathrm{f}$ \\
\hline & $100 \mathrm{mM} \mathrm{NaCl}$ & $17.2 \mathrm{de}$ & $8.1 d$ & $25.3 f$ & $2.2 \mathrm{bc}$ & $2.2 \mathrm{de}$ \\
\hline & Mn (Ippm) & $25.6 \mathrm{~b}$ & $9.0 \mathrm{lcd}$ & $34.6 \mathrm{lc}$ & $2.84 a$ & $3.5 c$ \\
\hline & $\mathrm{Mn}+50 \mathrm{mM} \mathrm{NaCl}$ & $22.3 c$ & $9.3 c$ & $31.6 \mathrm{~d}$ & $2.39 b$ & $1.46 \mathrm{~g}$ \\
\hline & $\mathrm{Mn}+100 \mathrm{mM} \mathrm{NaCl}$ & I8.Id & $9 \mathrm{~cd}$ & 27.le & $2.0 \mathrm{lc}$ & $2.4 d$ \\
\hline \multirow{6}{*}{ Ghara uzum } & 0 (Control) & $25.1 \mathrm{~b}$ & $13.68 \mathrm{~b}$ & $38.78 \mathrm{~b}$ & $1.83 \mathrm{~d}$ & $6.55 a$ \\
\hline & $50 \mathrm{mM} \mathrm{NaCl}$ & $15.66 \mathrm{e}$ & $9.67 c$ & $25.33 \mathrm{f}$ & $1.62 \mathrm{e}$ & $2.11 \mathrm{e}$ \\
\hline & $100 \mathrm{mM} \mathrm{NaCl}$ & $11.2 \mathrm{~g}$ & $5.5 \mathrm{e}$ & $16.7 \mathrm{~h}$ & $2.03 c$ & $0.54 \mathrm{i}$ \\
\hline & $\mathrm{Mn}(\mathrm{Ippm})$ & $12.6 \mathrm{fg}$ & $7.9 \mathrm{de}$ & $20.5 \mathrm{~g}$ & $1.59 \mathrm{f}$ & $2.34 d$ \\
\hline & $\mathrm{Mn}+50 \mathrm{mM} \mathrm{NaCl}$ & 17.22de & $8.5 \mathrm{~d}$ & $25.72 f$ & $2.02 \mathrm{c}$ & $2.2 \mathrm{de}$ \\
\hline & $\mathrm{Mn}+100 \mathrm{mM} \mathrm{NaCl}$ & $13.18 \mathrm{f}$ & $5.8 \mathrm{e}$ & 18.98gh & $2.27 \mathrm{bc}$ & $0.8 \mathrm{lh}$ \\
\hline
\end{tabular}

Each value is the mean $( \pm \mathrm{SE})$ of four replicates. Different letters in each column show significant difference at $p<0.05$ by Duncan's Test

The application of Mn together with saline stress increased chlorophyll $a$ content in both cultivars (5-14\% in Yaghoti and 10-18\% in Ghara uzum) compared to salinity alone (Table 2).

Applying Mn and saline stresses also increased the total carotenoids content in both cultivars; (Table 2).

The combination of salinity and Mn stresses increased soluble sugars content in both shoot and root (Figure 1). Compared to the control group, the saline stress plants increased shoot soluble sugars in Ghara uzum and Yaghoti by, $70-87 \%$ and $25-38 \%$, respectively (Figure 1A). Mn and salinity increased shoot soluble sugars in Yaghoti cultivar by $14 \%$ more than salinity alone. The salinity and Mn caused a decrease of $53-80 \%$ in root soluble sugars in Ghara uzum and an increase of nearly $28 \%$ in the $100 \mathrm{mM}$ salinity treatment in Yaghoti when compared to salinity alone (Figure 1B).
The effects of salinity on $\mathrm{Na}^{+}, \mathrm{Cl}^{-}$and $\mathrm{K}^{+}$content $\left(\mathrm{mgg}^{-1} \mathrm{DW}\right)$ and $\mathrm{K}^{+} / \mathrm{Na}^{+}$ratio are shown in Figures $2-5$ in the shoots and roots of 45-day-old plants after 30days of $\mathrm{NaCl}$ and $\mathrm{Mn}$ treatment.

The concentration of 50 and $100 \mathrm{mmol} \mathrm{L}^{-1} \mathrm{NaCl}$ in Yaghoti plants increased by $200-450 \%$ in shoot $\mathrm{Na}^{+}$(Figure $2 \mathrm{~A}$ ), $17-21 \%$ in root $\mathrm{Na}^{+}$(Figure 2B), 240-400\% in shoot $\mathrm{Cl}^{-}$(Figure 4A), and 22-128\% in root $\mathrm{Cl}^{-}$(Figure 4B). In Ghara uzum this increased was $560-1200 \%$ in shoot $\mathrm{Na}^{+}$(Figure 2A), 260-450\% in root $\mathrm{Na}^{+}$(Figure 2B), 500-1100\% in shoot $\mathrm{Cl}^{-}$(Figure 4B), and 500-8200\% in root $\mathrm{Cl}^{-}$(Figure 4B). In contrast, salinity in Yaghoti cultivar decreased by $39-44 \%$ in shoot $\mathrm{K}^{+}$(Figure 3A), 85-91\% in root $\mathrm{K}^{+}$(Figure 3B), 80-90\% in shoot $\mathrm{K}^{+} /$ $\mathrm{Na}^{+}$ratio (Figure 5A) and $85-91 \%$ in root $\mathrm{K}^{+} / \mathrm{Na}^{+}$ratio (Figure $5 \mathrm{~B}$ ) compared to the control group, and by about $27-32 \%$ in shoot $\mathrm{K}^{+}$, $34-87 \%$ in root $\mathrm{K}^{+}, 89-95 \%$ in shoot $\mathrm{K}^{+} / \mathrm{Na}^{+}$ratio, and $82-98 \%$ in root $\mathrm{K}^{+} / \mathrm{Na}^{+}$ratio in Ghara uzum cultivar compared to the control group (Figure 5). 


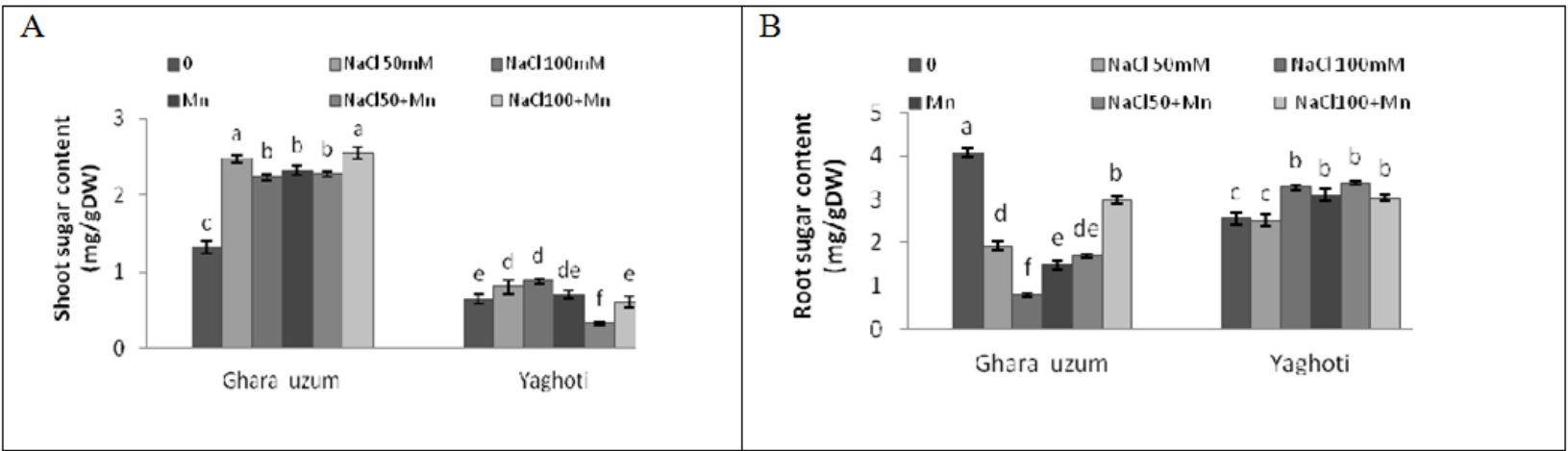

Figure I Effects of $\mathrm{Mn}$ (I Ipp) on soluble sugar content in shoots (A) and roots (B) in two cultivars of grapevine (Yaghoti and Ghara uzum) plants cultivated under saline stress $(0,50$ and $100 \mathrm{mM} \mathrm{NaCl})$. Each value is the mean $( \pm S E)$ of four replicates. Different letters on each column show significant difference at $\mathrm{p}<0.05$ by Duncan's Test.

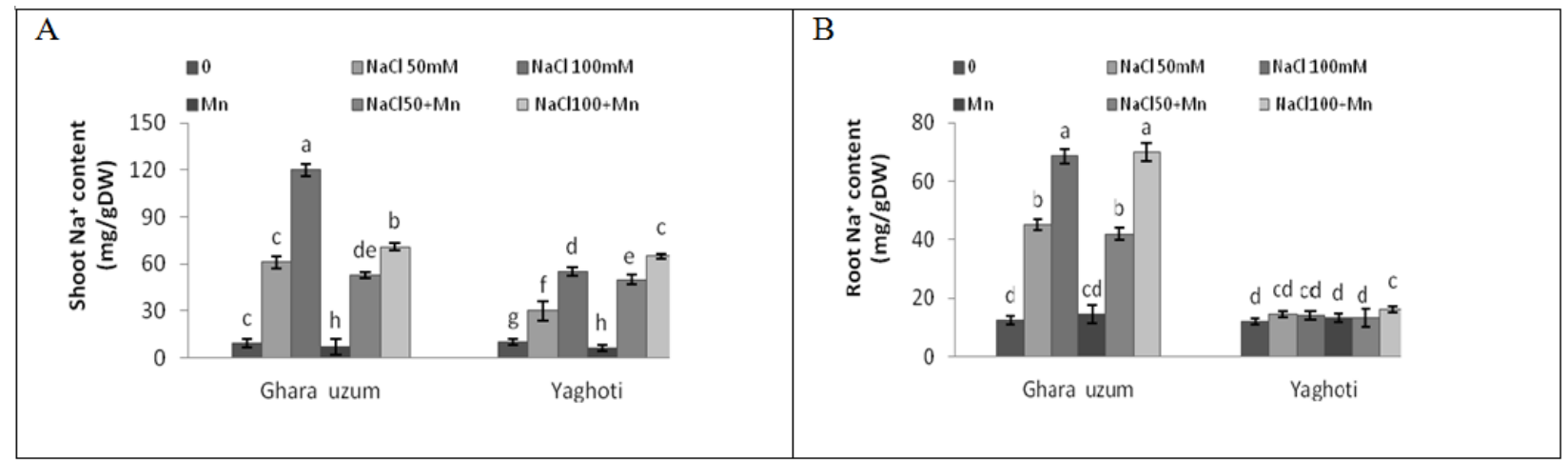

Figure 2 The effects of $\mathrm{Mn}(\mathrm{Ippm})$ on concentration of $\mathrm{Na}^{+}$in shoots $(\mathrm{A})$ and roots (B) in two grapevine cultivars (Yaghoti and Ghara uzum) cultivated under saline stress $(0,50$ and $100 \mathrm{mM} \mathrm{NaCl})$. Each value is the mean $( \pm S E)$ of four replicates. Different letters on each column show significant difference at $p<0.05$ by Duncan's Test.

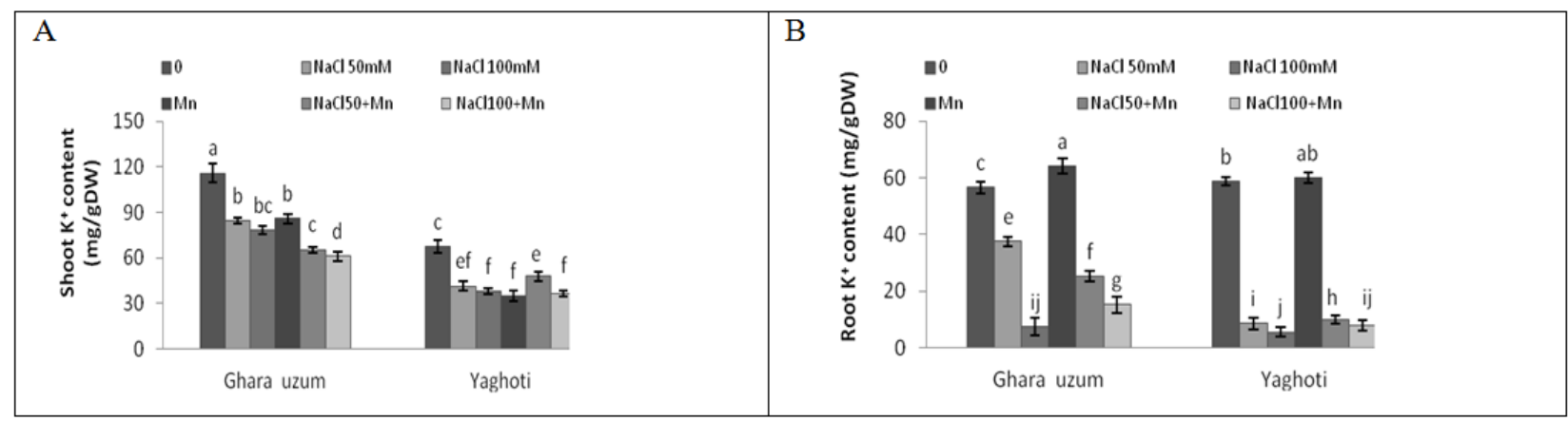

Figure 3 Effects of $\mathrm{Mn}$ ( I ppm) on concentration of $\mathrm{K}^{+}$in shoots (A) and roots (B) in two grapevine cultivars (Yaghoti and Ghara uzum) plants cultivated under saline stress $(0,50$ and $100 \mathrm{mM} \mathrm{NaCl})$. Each value is the mean $( \pm S E)$ of four replicates. Different letters on each column show significant difference at $p<0.05$ by Duncan's Test.

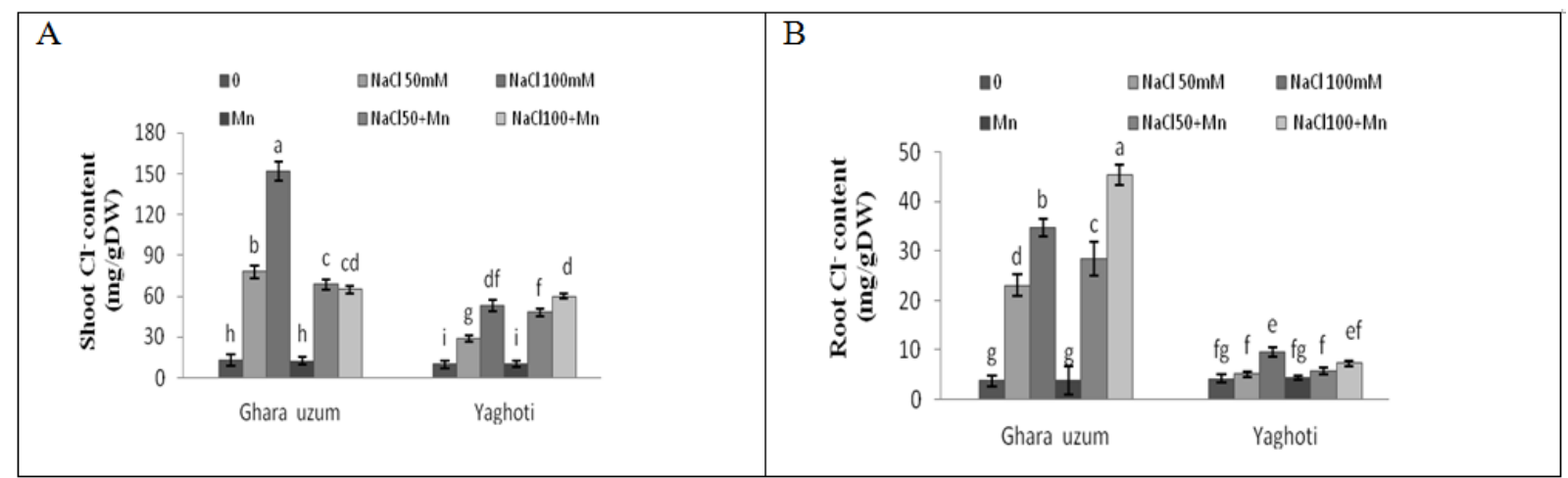

Figure 4 Effects of $\mathrm{Mn}$ (Ippm) on concentration of $\mathrm{Cl}^{-}$in shoots (A) and roots (B) in two grapevine cultivars (Yaghoti and Ghara uzum) cultivated under saline stress $(0,50$ and $100 \mathrm{mM} \mathrm{NaCl})$. Each value is the mean $( \pm \mathrm{SE})$ of four replicates. Different letters on each column show significant difference at $p<0.05$ by Duncan's Test.

Citation: Hatami S, Pourakbar L. Effects of manganese on physiological characters of grapevine cultivars under salinity stress. MOJ Eco Environ Sci. 2020;5(2):62-68. DOI: 10.15406/mojes.2020.05.00177 


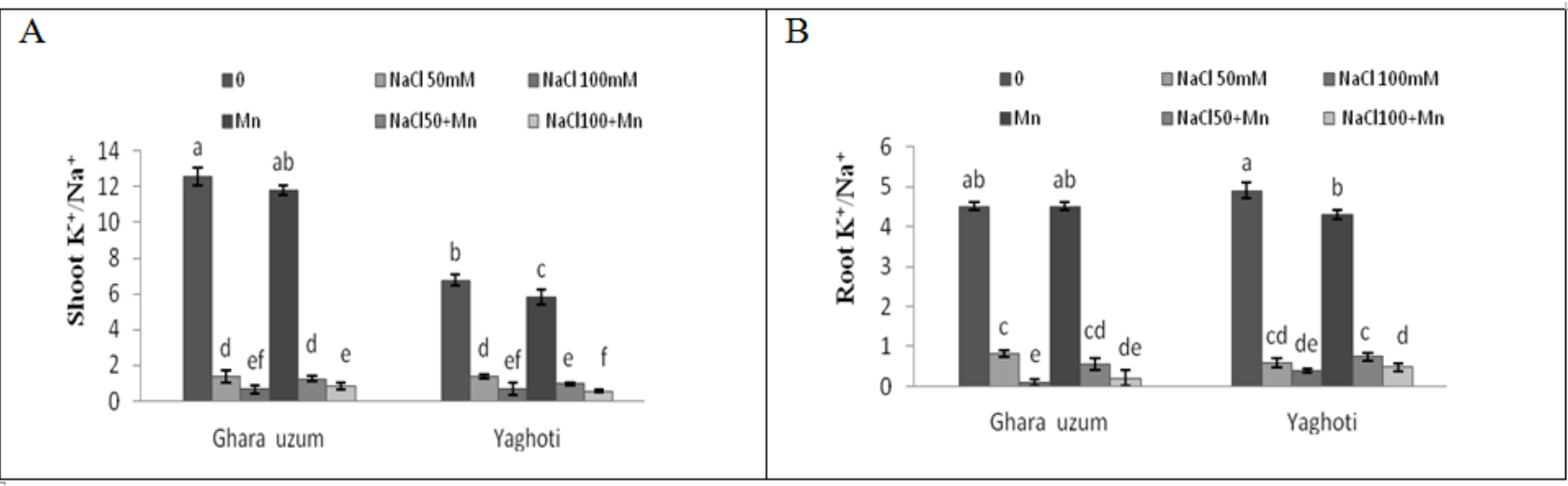

Figure 5 Effects of $\mathrm{Mn}(\mathrm{Ippm})$ on $\mathrm{K}^{+} / \mathrm{Na}^{+}$ratio in shoots $(\mathrm{A})$ and roots $(\mathrm{B})$ in two grapevine cultivars (Yaghoti and Ghara uzum) cultivated under saline stress $(0,50$ and $100 \mathrm{mM} \mathrm{NaCl})$. Each value is the mean $( \pm \mathrm{SE})$ of four replicates. Different letters on each column show significant difference at $p<0.05$ by Duncan's Test.

Application of Mn together with saline stress led to an increase in the accumulation of $\mathrm{Na}^{+}$and $\mathrm{Cl}^{-}$ions in Yaghoti cultivar about 18$66 \%$ in shoot $\mathrm{Na}^{+}, 15.7 \%$ in $\operatorname{root} \mathrm{Na}^{+}(\mathrm{Mn}+100 \mathrm{mM} \mathrm{NaCl}), 12-65 \%$ in shoot $\mathrm{Cl}^{-}, 11 \%$ in root $\mathrm{Cl}^{-}(\mathrm{Mn}+50 \mathrm{mM} \mathrm{NaCl}), 18-41 \%$ in root $\mathrm{K}^{+}$, and $23-29 \%$ in root $\mathrm{K}^{+} / \mathrm{Na}^{+}$ratio. Similarly in Ghara uzum cultivar this led to an increase of $2 \%$ in root $\mathrm{Na}^{+}, 106 \%$ in root $\mathrm{K}^{+}(\mathrm{Mn}+100 \mathrm{mM}$ $\mathrm{NaCl}), 23-30 \%$ in root $\mathrm{Cl}^{-}$, and $96 \%$ in root $\mathrm{K}^{+} / \mathrm{Na}^{+}$ratio $(\mathrm{Mn}+100$ $\mathrm{mM} \mathrm{NaCl}$ ). In contrast, applying $\mathrm{Mn}$ together with salinity in Ghara uzum cultivar led to a decrease in shoot $\mathrm{Na}^{+}(14-40 \%)$, root $\mathrm{Cl}^{-}(12-$
$57 \%)$, and root $\mathrm{K}^{+} / \mathrm{Na}^{+}$ratio $(30 \%$ in $\mathrm{Mn}+50 \mathrm{mM} \mathrm{NaCl})$. Similarly in Yaghoti cultivar this led to a decrease in root $\mathrm{Na}^{+}(9 \%$ in $\mathrm{Mn}+50 \mathrm{mM}$ $\mathrm{NaCl})$, root $\mathrm{Cl}^{-}(24 \%$ in $\mathrm{Mn}+100 \mathrm{mM} \mathrm{NaCl})$, and shoot $\mathrm{K}^{+} / \mathrm{Na}^{+}$ratio $(19-31 \%)$.

Based on our findings, however, salinity caused a significant decrease in $\mathrm{NO}_{3}^{-}$content in both cultivars (Figure 6). Applying $\mathrm{Mn}$ with salinity, compared with salinity alone, decreased the nitrate ion content in shoot of both grapevine cultivars (Figure 6).

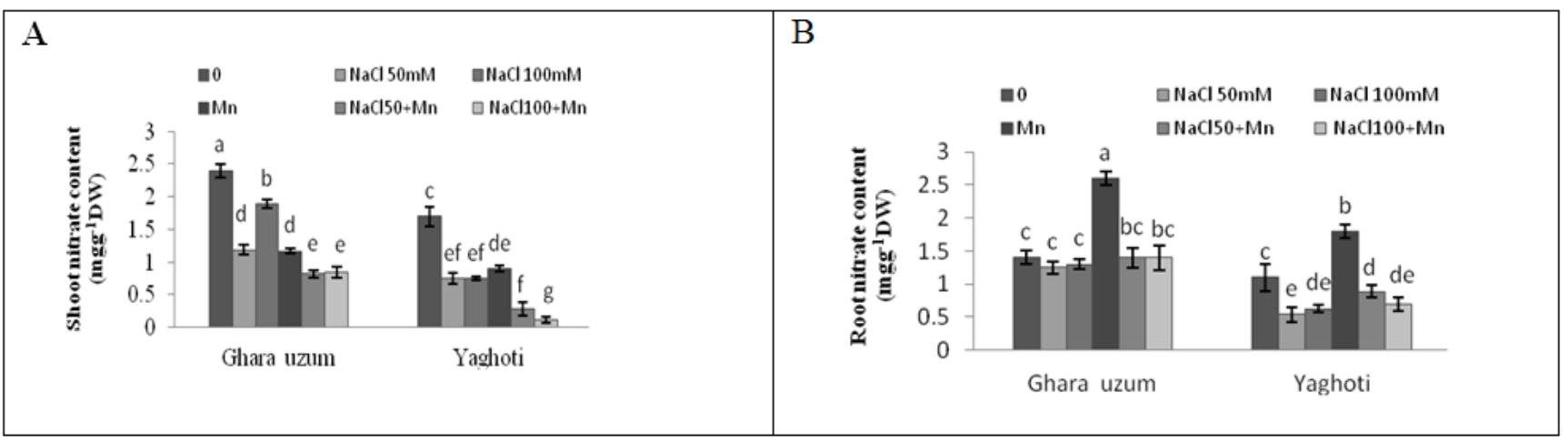

Figure 6 Effect of $\mathrm{Mn}$ (I ppm) on nitrate content in shoots (A) and roots (B) in two grapevine cultivars (Yaghoti and Ghara uzum) cultivated under saline stress $(0,50$ and $100 \mathrm{mM} \mathrm{NaCl})$. Each value is the mean $( \pm S E)$ of four replicates. Different letters on each column show significant difference at $p<0.05$ by Duncan's Test.

\section{Discussion}

The current study of indicated that saline stress and increased concentration of manganese resulted in a decrease in a vegetative growth. In support of these observations, Yasar et al. ${ }^{15}$ reported the amount-based decrease in the growth of the green bean plants under the influence of salinity. Although manganese is necessary for plant growth, its excessive amount, as reported in rice for example, can be an inhibitor. ${ }^{16}$

Mn excess in plants decreases the root and shoot lengths. ${ }^{17}$ The accumulation of salt and ions leads to osmotic and water stress which decreases water absorption in plant tissue leading to growth decrease in cells. The lower growth of shoot in high concentration of $\mathrm{Mn}$ can be related to its presence in some specific metabolic processes. ${ }^{6}$ Manganese may decrease leaf growth in some plants due to the inhibition in elongation and cell divisions. ${ }^{18}$
Simultaneous effects of $\mathrm{NaCl}$ and $\mathrm{Mn}$ on cell division and cell elongation intensified the reduction in shoot growth in Ghara uzum. In Yaghoti, however, the application of manganese together with salinity increased growth in the shoots more than salinity alone. It also adjusted the reduction caused by salinity. This contradiction can occur to some extent due to the variety of plant species and their genotypes and their various responses. ${ }^{19}$

$\mathrm{NaCl}$ and $\mathrm{Mn}$ treatments, separately or simultaneous, led to the accumulation of soluble sugars in the shoots of both Ghara uzum and Yaghoti cultivars, and also in the roots of Yaghoti. This is a prevailing event under stress. Garg et al. ${ }^{20}$ reported that total soluble sugars increase as a result of salinity increase, playing an important role in osmosis adjustment. ${ }^{21}$ Since salinity, besides ion toxicity, creates osmosis stress as a result of reduction in osmotic potential of soil matrix, the plants decrease their osmotic potential to adjust the osmosis. The osmotic potential reduction is the result of the increase 
in cell soluble materials, which is an adjustment and adaptation mechanism in plants against external stresse ${ }^{17}$ and helps the plant to maintain its tolerance in saline stress conditions. Increasing in soluble sugar concentrations can be regarded as a response to relative water content and the leaves' water potential, because increase of sucrose and other soluble sugars under saline conditions plays an important role in tolerance to salinity. This finding was consistent with Geholt et al. ${ }^{22}$ results (2005). The concentration of organic soluts, can contribute to the maintenance of ionic homeostasis and $\mathrm{C} / \mathrm{N}$ ratio; the removal of free radicals; and the stability of organs and macromolecules like proteins, protein complexes, and membranes. ${ }^{23}$

In this study, the chlorophyll $\mathrm{a}$ and $\mathrm{b}$, and the total carotenoids contents decreased under saline conditions and with the application of manganese. Chlorophyll is membrane-bound, and rarely remains healthy under saline stress. ${ }^{24}$ Decrease in chlorophyll content due to salinity has been reported by other researchers, and its decrease can be related to chlorophyll degrading enzyme (Chlorophyllase) ${ }^{25}$ High levels of sodium concentration in plant tissues have been reported as a major factor in the reduction of photosynthetic pigments and photosynthesis velocity. ${ }^{26}$

The decrease in chlorophyll content under heavy metal stress is only caused by the inhibition of biosynthesis since. The central Mg element existing in the chlorophyll structure is replaceable by other elements such as manganese, copper, zinc and nickel. This displacement is the major destruction caused by heavy metals in chlorophyll structure. ${ }^{27}$

In this study with increasing salinity, $\mathrm{Cl}^{-}$and $\mathrm{Na}^{+}$concentrations increased in the shoots and roots of the two cultivars of two grapevine cultivars, while $\mathrm{K}^{+}$and $\mathrm{NO}_{3}$ - concentrations decreased. This finding was consistent with Meloni et al. ${ }^{17}$ who reported that sodium and chlorine ions increased as potassium decreased. The accumulation of sodium and chlorine in plants leads to osmosis increase, which can help the plants deal with the osmosis potential decrease in the root environment. Being an essential element for plant growth, potassium absorption is inhibited by an increase in salinity; consequently the plant has no choice but to face its deficiency. In saline soils in which sodium concentration is high, the plants absorb high amounts of sodium instead of potassium and calcium, and this leads to calcium and potassium deficiency. Due to the structural similarity of sodium and potassium, and because of sodium's competition to replace potassium, potassium related metabolic processes are controlled in cytoplasm, and this indicates that cell sodium amounts must be kept at minimum level. ${ }^{28}$

The reason for nitrate reduction in plants exposed to manganese toxicity might be that their nitrate absorption has reduced because of toxicity. The low sodium concentration in plants under simultaneous $\mathrm{Mn}^{2+}$ and $\mathrm{NaCl}$ stress in comparison with those exposed to $\mathrm{NaCl}$ stress alone can be attributed to this toxicity-reducing effect of the metal which has been observed for other heavy metals like cadmium and zinc as well. ${ }^{29,30}$ Previously conducted studies reported that heavy metals such as manganese, zinc and cadmium in sufficient amounts are essential for plant resistance against $\mathrm{NaCl}$ toxicity. ${ }^{31}$ These elements are essential for cell membrane strength in roots, and thus control the membrane permeability. ${ }^{32-37}$

\section{Conclusion}

According to the results obtained from the present study, especially those concerning the growth characteristics, photosynthetic pigments content, the way the deleterious ions of $\mathrm{Na}^{+}$and $\mathrm{Cl}^{-}$accumulate, and the $\mathrm{K}^{+} / \mathrm{Na}^{+}$ratio which is a very determining factor in sensitivity and resistance of plants against salinity, it can generally be stated that Ghara uzum experienced much more reduction in growth characteristics and pigments content compared to Yaghoti; and $\mathrm{Na}^{+}$and $\mathrm{Cl}^{-}$ions accumulation in the shoots was higher in the former cultivar.

Manganese caused growth limitation in both cultivars, and it was found that Yaghoti was more resistant to Mn than Ghara uzum.

In the simultaneous application of salinity and manganese, and through examining $\mathrm{Na}^{+}$and $\mathrm{Cl}^{-}$accumulation, it was observed that the application of manganese had more impact on decreasing salinity toxicity in Ghara uzum compared to that in Yaghoti. Through the application of Manganese, $\mathrm{Na}^{+}$accumulation was reduced by $40 \%$ in Ghara uzum, while in Yaghoti not only there was no decrease in $\mathrm{Na}^{+}$ accumulation in the shoot, but also the salinity stress was intensified in this cultivar. The results also indicated that the responses of the two cultivars to saline, manganese, and their interactivity were different. This difference in responses was to some extent due to the species of the plants, their genotypes and their different responses.

\section{Acknowledgments}

None.

\section{Funding}

None.

\section{Conflicts of interest}

The authors declare there are no conflicts of interest.

\section{References}

1. Sairam RK, Tyagi A. Physiology and molecular biology of salinity stress tolerance in plants. Curr Sci India. 2004;86:3-10.

2. Zhang JL, Flowers TJ, Wang SM. Mechanisms of sodium uptake by roots of higher plants. Plant Soil. 2010;326:45-60.

3. Flowers TJ, Yeo AR. Ionrelation of salt tolerance. In: Baker DA, Hall JL, editors. Solute transport in plant cells and tissues. Harlow: Longman Scientific and Technical; 1988:392-413.

4. Hajlaoui H, Denden M, Bouslama M. Effect du chlorue de sodium sur les criteres morpho-physiologiques et productifs du pois chiche (Cicer arietinum L.). Eaux et Forets. 2006;8:171-187.

5. Doncheva C, Poschenrieder C, Stoyanova ZI, et al. Silicon amelioration of manganese toxicity in Mn-sensitive and Mn-tolerant maize varieties. Environ Exp Bot. 2009;65:189-197.

6. Ducic T, Polle A. Transport and detoxification of manganese and copper in plants. Braz J Plant Physiol. 2005;17:103-112.

7. Papadakis IE, Giannakoula A, Therios IN, et al. Mn-induced changes in leaf structure and chloroplast ultrastructue of Citrus volkameriana (L.) plants. J Plant Physiol. 2007;164(1):100-103.

8. Goussias C, Boussac A, Rutherford W. Photosystem II and photosynthetic oxidation of water: an overview. Phil Trans R Soc Lond B. 2002;357:13691381.

9. Millalo R, Reyes-Diaz M, Ivanov AG, et al. Manganese as essential and toxic element for plants: Transport, accumulation and resistance mechanisms. J Soil Sci Plant Nutr. 2010;10(4):476-494.

10. Hauck M, Paul A, Gross S, et al. Manganese toxicity in epiphytic lichens: chlorophyll degradation and interaction with iron and phosphorus. Environ Exp Bot. 2003;49(2):181-191. 
11. Hu Y, Schmidhalter U. Drought and salinity: a comparison of their effects on mineral nutrition of plants. J Plant Nutr Soil Sci. 2005;168:541-549.

12. Cramer GR, Epstein E, Lauchli A, Effects of sodium, potassium and calcium on salt stressed barley. II. Elemental analysis. Physiol Plant. 1991;80(1):197-202.

13. Lichtenthaler HK, Wellburn AR. Determination of total carotenoids and chlorophylls a and b of leaf in different solvents. Biochem Soc Trans. 1985:591-592.

14. Allen SK, Dobrenz AK, Schonhortst $\mathrm{MH}$, et al. Heritability of $\mathrm{NaCl}$ tolerance in germinating alfalfa seeds. Agron J. 1985;77:90-96.

15. Yasar F, Ellialtioglu S, Yildiz K. Effect of salt stress on antioxidant defense systems, lipid peroxidation, and chlorophyll content in green bean. Russ J Plant Physiol. 2008;55(6):782-786.

16. Lidon F. Tolerance of rice to excess manganese in the early stages of vegetative growth. Characterization of manganese accumulation. Plant Physiol. 2001;158(10):1341-1348.

17. Meloni DA, Oliva MA, Martinez CA, et al. Photosynthesis and activity of superoxide dismutase, peroxidase and glutathione reductase in cotton under salt stress. Environ Exp Bot. 2003;49(1):69-76.

18. Marschner H. Mineral nutrition in higher plants. London, Orlando, San Diego, USA, Academic Pres; 1986:477-542.

19. Mane AV, Deshpande TV, Wagh VB, et al. A critical review on physiological changes associated with reference to salinity. Int J Environ Sci. 2011;1(6):1192-1216.

20. Garg AK, Ownes JK, Wu RJ. Trehalose accumulation in rice plants confers high tolerance levels to different abiotic stress. Proc Nat Acad Sci. 2002;99:15898-15903.

21. Williams LE, Lemonie R, Saucer N. Sugars transporters in higher plants: a diversity of roles and complex regulation trends. Plant Sci. 2000;5(7):283-290.

22. Geholt HS, Purohit A, Shekhawat NS. Metabolic changes and protein patterns associated with adaptation to salinity in Sesamun indicum cultivars. J Cell Mol Biol. 2005;4:31-39.

23. Bray EA, Bailey-Serres J, Weretilnyk E. Responses to abiotic stresses. In: Buchanan BB, Gruissem W, Jones RL, editors. Biochemistry and Molecular Biology of Plants. ASPP, Rockville; 2000:1158-1203.

24. Shilpim M, Narendra T. Cold, salinity and drought stresses: An overview. Arch Biochem Biophys. 2005;444(2):139-158.

25. Noreen Z, Ashraf M. Changes in antioxidant enzymes and some key metabolites in some genetically diverse cultivars of radish (Raphanus sativus L.). Environ Exp Bot. 2009;67(2):395-402.
26. Ashraf M. Some important physiological selection criteria for salt tolerance in plants. Flora. 2004;199(5):361-376.

27. Kupper H, Kiipper F, Spiller M. Environmental relevance of heavy metal substituted chlorophylls using the example of water plants. Environ Exp Bot. 1996;47:259-266.

28. Yan-de J, Zhen-Li HE, Xiao-e Y. Role of soil rhizobacteria in phytoremediation of heavy metal contaminated soils. J Zhejiang Univ Sci B. 2007;8(3):192-207.

29. Huang YZ, Wei K, Yang J, et al. Interaction of salinity and cadmium stresses on mineral nutrients, sodium, and cadmium accumulation in four barley genotypes. J Zhejiang Univ Sci B. 2000;8(7):476-485.

30. Weisany W, Sohrabi Y, Heidari G, et al. Physiological responses of soybean (Glycine $\max$ L.) to zinc application under salinity stress. AJCS. 2011;5(11):1441-1447.

31. Welch RM, Webb MJ, Lonegaran JF. Zinc in membrane function and its role in phosphorus toxicity. Proc. $9^{\text {th }}$ International Plant Nutrition. UK; 1982:710-715.

32. Anisur R, Shahadat Hossain Md, Al Mahmud J, et al. Manganese-induced salt stress tolerance in rice seedlings: regulation of ion homeostasis, antioxidant defense and glyoxalase systems. Physiol Mol Biol Plants. 2016;22(3):291-306.

33. Dong Y, Ji T, Dong S. Stress responses to rapid temperature changes of the juvenile sea cucumber (Apostichopus japonicus Selenka). J of Ocean Univ. Chin 2007;6:275-280.

34. Foy C, Scott B, Fisher J. Genetic differences in plant tolerance to manganese toxicity. In: Graham RD, Hannam RJ, Uren NJ, editors. Manganese in Soil and Plants. Dordrecht, Netherlands: Kluwer Academic Publishers; 1998:293-307.

35. Gulzar S, Khan MA, Ungar IA. Effects of salinity on growth, ionic content, and plant-water status of Aeluropus lagopoides. Comm Soil Scie Plant. 2003;34:1657-1668.

36. Ke Shi-Sheng WS, Xiong ZT, Chen SJ, et al. Effects of copper and mineral nutrition on growth, copper accumulation and mineral element uptake in two Rumex japonicus populations from a copper mine and an uncontaminated field sites. Environ Exp Bot. 2007;59(1):59-67.

37. Sarkar D, Pandey S, Sud K, et al. In vitro characterization of manganese toxicity in relation to phosphorus nutrition in potato (Solanum tuberosum L.). Plant Sci. 2004;167(5):977-986. 